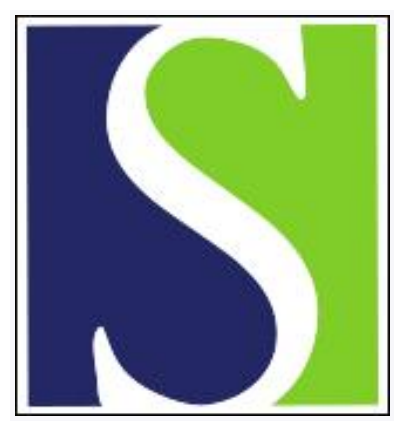

Scand J Work Environ Health 1999;25(3):207-214

https://doi.org/10.5271/sjweh.425

Issue date: Jun 1999

Occupational exposure and cancer incidence among workers from an aluminum smelter in western Norway

by Rønneberg A, Haldorsen T, Romundstad P, Andersen A

The following articles refer to this text: 2008;34(6):463-470;

2010;36(1):71-79; 2023;49(3):211-221

Key terms: bladder cancer; cohort study; electrical discharge; electrician; electromagnetic fields; heat; lung cancer; maintenance; pancreatic cancer; polycyclic aromatic hydrocarbon

This article in PubMed: www.ncbi.nlm.nih.gov/pubmed/10450770

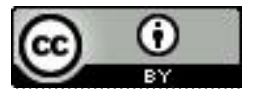




\title{
Occupational exposure and cancer incidence among workers from an aluminum smelter in western Norway
}

\author{
by Alf Rønneberg ${ }^{\dagger}, M S c,{ }^{1}$ Tor Haldorsen, MSc, ${ }^{1}$ Pål Romundstad MSc, ${ }^{1}$ Aage Andersen ${ }^{1}$
}

\begin{abstract}
Rønneberg A, Haldorsen T, Romundstad P, Andersen A. Occupational exposure and cancer incidence among workers from an aluminum smelter in western Norway. Scand J Work Environ Health 1999;25(3):207-214.
\end{abstract}

Objectives This study investigated the associations between specific cancers and occupational exposure to polycyclic aromatic hydrocarbons ( $\mathrm{PAH})$, asbestos, electromagnetic fields, and heat in a cohort of workers from a Norwegian aluminum smelter.

Methods Cancer incidence between 1953 and 1993 was observed for 2647 male short-term workers and 2 cohorts of men with at least 4 years' employment (2888 production workers and 373 maintenance workers). Standardized incidence ratios (SIR) were calculated from the national male cancer incidence, and associations with cumulative exposure were investigated by stratified analysis. Cumulative exposure in 15-year time windows was used as an alternative dose indicator.

Results Investigation of the a priori hypotheses in the production cohort revealed a positive association between bladder cancer and PAH exposure 30 years or more before observation. The results also suggested an association between PAH and pancreatic cancer, although not statistically significant. No association was seen between exposure to $\mathrm{PAH}$ and cancers of the lungs or between magnetic field exposure and lymphatic and hematopoietic cancer. In the maintenance cohort there was a positive association between employment as an electrician and lymphatic and hematopoietic cancer and a statistically nonsignificant association between PAH and lung cancer. The short-term workers showed a statistically significant excess of lung cancer.

Conclusions The results support previous findings of an association between exposure to PAH and bladder cancer.

Key terms bladder cancer, cohort study, electrical discharge, electrician, electromagnetic fields, heat, lung cancer, maintenance, pancreatic cancer, polycyclic aromatic hydrocarbons.

In the first study of cancer in the Norwegian aluminum industry Andersen and co-workers (1) observed employees from 4 smelters between 1953 and 1979. An extended follow-up (until 1991) of workers from the smelter in Eydehavn (2) supported earlier findings of an association between exposure to coal tar pitch volatiles - tar - and cancers of the bladder (3-5) and lungs $(3,6)$. These cancers appeared to be associated primarily with exposure to tar at least 35 years before observation.

This report concerns the Årdal smelter, which contributed almost half of the participants to the first study (1). Lung cancer was in excess among the Ardal workers at that time when compared with the local incidence, but there was a deficit when compared with the national level (7).
On the basis of a review (8) and results from our previous study (2) we chose, in the present study, to investigate the associations between polycyclic aromatic hydrocarbons (PAH) and cancers of the urinary bladder, lungs and pancreas; asbestos and cancer of the lung and pleura; magnetic fields and cancers of the brain and lymphatic and hematopoietic tissue; heat and kidney cancer.

\section{Subjects and methods}

The smelter started production in $1948-1950$ in a potroom with Søderberg electrolytic cells with horizontal current supply studs. From 1949 on a carbon plant

$\dagger \quad$ Deceased (May 1997).

1 The Cancer Registry of Norway, Institute of Epidemiological Cancer Research, Oslo, Norway.

Reprint requests to: Aage Andersen, The Cancer Registry of Norway, Montebello, N-0310 OSLO, Norway. [E-mail: aage.andersen@kreftreg.no] 
produced anode paste from petroleum coke and coal-tar pitch. Three vertical stud Søderberg potrooms were added between 1959 and 1962. In the Søderberg cell the anode paste was baked by the process heat, and coal-tar pitch volatiles were emitted to the potroom atmosphere.

Prebake cells were introduced in 3 potrooms between 1959 and 1970. This cell type used anodes that had been baked in furnaces at the carbon plant and which contained negligible amounts of volatile material when used in the potroom.

\section{Study design}

The investigation was designed as a cohort study of cancer incidence between 1953 and 1993. For this period complete coverage of the population for cancer sites other than basal cell carcinoma of the skin are available in the cancer register of Norway. The smelter's personnel files contained name, date of birth, and work histories for all persons employed since 1946. The date of death had also been recorded if known to the company.

The study included all men first hired at an hourly wage and with at least 6 months of continuous employment. Men first hired at a monthly salary were excluded since the prevalence of smoking in this group may have differed from that of the blue-collar workers.

The Central Bureau of Statistics provided the date of all deaths from 1953, personal identification numbers for those alive at the census in 1960, and the date of all emigrations from 1964 on. Of the 5962 men who satisfied the inclusion criteria, 6 had died before the observation started in 1953, and 48 men were lost to follow-up. Most of these men had probably died before 1960 or emigrated before 1964. There were therefore 5908 men left in the final cohort.

Each person was observed for cancer or death from 1 January 1953 or the time of hire if later. Observation continued until 31 December 1993 or to the time of death or emigration. Cancer cases were identified from the cancer register through each cohort member's name and date of birth between 1953 and 1960 and his personal identification number in 1961 or later.

\section{Analysis of dose-response relations}

The standardized incidence ratio (SIR) was calculated as the ratio between the observed and expected number of cancer cases. The expected number was calculated from the annual national incidence for men by 5-year age groups. The $95 \%$ confidence interval $(95 \% \mathrm{CI})$ was calculated on the assumption of the Poisson distribution for the observed number.

Dose-response relations were investigated in a stratified analysis of the SIR values of the production and maintenance cohorts. We used cumulative exposure as an indicator of individual dose. This value was calculated for each person-year under observation as the product of exposure intensity and duration summed for all jobs held at the smelter. Thus each person could contribute person-time to more than 1 stratum in each analysis. Unexposed person-time constituted 1 stratum, and the exposed person-time was divided into 3 strata with roughly equal numbers of person-years in each group.

As an alternative dose indicator, we used cumulative exposure attained within 15-year time windows. This approach assumes that a sufficient dose to contribute to the disease process is received during a limited induction period, which can be preceded or followed by a period when other causes influence the disease process (9).

All analyses were carried out with the Epicure software package (10). The significance of each association was assessed with the Poisson trend statistic (2-sided) (11). It should be noted that this test yields approximate $\mathrm{P}$-values that must be interpreted with caution, particularly when the number of observed or expected cases is small.

\section{Exposure estimation}

The job-exposure matrix for PAH and fluorides was based on more than 4000 area samples of fluorides and about 1600 personal samples of fluorides and PAH (table 1). We used a statistical analysis of area measurements sampled since 1962 and personal measurements sampled since 1976 to identify jobs and periods with significantly different exposure to PAH and fluorides. Potroom exposures before 1962 were extrapolated backwards using multipliers based on descriptions of conditions noted in the smelter's annual reports since 1949.

The measurement data were analyzed by multiple linear regression with BMDP statistical software (12). The influence of job and calendar year on exposure was investigated by applying a log transformed regression model to the measurement data. Exposure categories were then constructed by combining all jobs which did not differ significantly with respect to either $\mathrm{PAH}$ or fluoride exposure. Consecutive years that did not differ significantly by area samples were combined with the exposure periods.

For periods only covered by area samples of fluoride, we used the ratio between personal PAH exposure and area fluoride concentration as measured in 1976 to estimate exposure to PAH. For potrooms A and B we used measurement data from a Swedish aluminum smelter with similar technology. The final matrix for PAH and fluorides included estimates for 115 combinations of department, exposure category, and period. For many of these combinations, exposure to some agents was estimated to be nil. The range of nonzero estimates was 2$1700 \mu \mathrm{g} / \mathrm{m}^{3}$ for total particulate PAH and $0.1-2.5 \mathrm{mg} /$ $\mathrm{m}^{3}$ for total fluorides (gaseous and particulate). The fraction of benzo[a]pyrene in particulate $\mathrm{PAH}$ was typically $5 \%(13,14)$, and the amount of PAH relative to total 
Table 1. Exposure to fluorides and polycyclic aromatic hydrocarbons ( $P A H$ ) by exposure category and period in the potrooms and paste plant. (HSS=horizontal stud Søderberg anodes, VSS = vertical stud Søderberg anodes, $\mathrm{PB}=$ prebaked anodes)

\begin{tabular}{|c|c|c|}
\hline Department & Fluorides $\left(\mathrm{mg} / \mathrm{m}^{3}\right)$ & $\mathrm{PAH}(\mu g / n$ \\
\hline \multicolumn{3}{|c|}{ Potrooms A-B (32 kA HSS) } \\
\hline \multicolumn{3}{|c|}{ All jobs } \\
\hline $1948-1953$ & 2.5 & 173 \\
\hline $1954-1964$ & 2.2 & 156 \\
\hline 1965-1969 & 1.6 & 114 \\
\hline \multicolumn{3}{|c|}{ Potrooms A-B (32 kA hooded PB) } \\
\hline \multicolumn{3}{|c|}{ Tapping crew } \\
\hline $1970-1979$ & 0.1 & 5 \\
\hline $\begin{array}{l}1980-1986 \\
1987-1993\end{array}$ & 0.2 & 10 \\
\hline \multicolumn{3}{|l|}{ Sweeper } \\
\hline $1970-1979$ & 1.0 & 5 \\
\hline $1980-1986$ & 1.8 & 10 \\
\hline $1987-1993$ & 0.2 & \\
\hline \multicolumn{3}{|l|}{ Other jobs } \\
\hline $1970-1979$ & 0.5 & 5 \\
\hline $1980-1986$ & 0.9 & 10 \\
\hline $1987-1993$ & 0.4 & 5 \\
\hline \multicolumn{3}{|c|}{ Potroom Ca (150 kA Open PB) } \\
\hline \multicolumn{3}{|l|}{ All jobs } \\
\hline $1959-1969$ & 1.9 & 50 \\
\hline $1970-1971$ & 1.2 & 41 \\
\hline $1978-1986$ & 0.5 & 22 \\
\hline 1987-1993 & 0.2 & 7 \\
\hline \multicolumn{3}{|c|}{ Potroom $D^{b}$ (150 kA VSS) } \\
\hline \multicolumn{3}{|c|}{ Stud puller, rod raiser } \\
\hline $1959-1969$ & 0.9 & 1669 \\
\hline $1970-1974$ & 0.4 & 697 \\
\hline $1975-1985$ & 0.1 & 297 \\
\hline \multicolumn{3}{|l|}{ Tapping crew } \\
\hline $1959-1969$ & 0.8 & 57 \\
\hline $1970-1974$ & 0.6 & 47 \\
\hline $1975-1979$ & 0.2 & 15 \\
\hline $1980-1985$ & 0.3 & 25 \\
\hline \multicolumn{3}{|c|}{ Sweeper, process controller } \\
\hline 1959-1969 & 2.4 & 550 \\
\hline $1970-1974$ & 2.0 & 459 \\
\hline $1975-1979$ & 0.6 & 147 \\
\hline $1980-1985$ & 1.1 & 244 \\
\hline \multicolumn{3}{|l|}{ Other jobs } \\
\hline $1959-1969$ & 1.0 & 264 \\
\hline $1970-1974$ & 0.8 & 220 \\
\hline $1975-1979$ & 0.3 & 70 \\
\hline $1980-1985$ & 0.4 & 117 \\
\hline \multicolumn{3}{|c|}{ Potrooms E-F (110A VSS) } \\
\hline \multicolumn{3}{|c|}{ Stud puller, rod raiser } \\
\hline $1962-1964$ & 0.2 & 423 \\
\hline $1965-1969$ & 0.4 & 823 \\
\hline $1970-1974$ & 0.6 & 1157 \\
\hline $1975-1985$ & 0.1 & 676 \\
\hline 1986 & 0.1 & 55 \\
\hline 1987-1993 & 0.1 & 8 \\
\hline \multicolumn{3}{|l|}{ Tapping crew } \\
\hline $1962-1964$ & 0.2 & 14 \\
\hline $1965-1969$ & 0.4 & $\begin{array}{l}28 \\
30\end{array}$ \\
\hline $1970-1974$ & 0.5 & $\begin{array}{l}39 \\
23\end{array}$ \\
\hline $\begin{array}{l}1975-1985 \\
1986\end{array}$ & $\begin{array}{l}0.3 \\
0.3\end{array}$ & $\begin{array}{l}23 \\
43\end{array}$ \\
\hline $1987-1993$ & 0.3 & 7 \\
\hline
\end{tabular}

(continued)
Table 1. Continued.

\begin{tabular}{|c|c|c|}
\hline Department & Fluorides $\left(\mathrm{mg} / \mathrm{m}^{3}\right)$ & $\operatorname{PAH}\left(\mu \mathrm{g} / \mathrm{m}^{3}\right)$ \\
\hline \multicolumn{3}{|c|}{ Sweeper, process controller } \\
\hline $1962-1964$ & 0.6 & 139 \\
\hline $1965-1969$ & 1.2 & 271 \\
\hline $1970-1974$ & 1.7 & 382 \\
\hline $1975-1985$ & 1.0 & 223 \\
\hline 1986 & 1.0 & 48 \\
\hline $1987-1993$ & 0.3 & 7 \\
\hline \multicolumn{3}{|l|}{ Other jobs } \\
\hline $1962-1964$ & 0.2 & 67 \\
\hline $1965-1969$ & 0.5 & 130 \\
\hline $1970-1974$ & 0.7 & 183 \\
\hline $1975-1985$ & 0.4 & 107 \\
\hline 1986 & 0.4 & 27 \\
\hline $1987-1993$ & 0.2 & 8 \\
\hline \multicolumn{3}{|l|}{ Paste plant } \\
\hline \multicolumn{3}{|l|}{ All workers } \\
\hline $1949-1969$ & 0.0 & 112 \\
\hline \multicolumn{3}{|c|}{ Mixer, paste worker, cathode worker } \\
\hline $1970-1980$ & 0.0 & 78 \\
\hline $1981-1985$ & 0.0 & 56 \\
\hline $1986-1993$ & 0.0 & 26 \\
\hline
\end{tabular}

${ }^{a}$ Closed between 1971 and 1978.

b Closed in 1985

benzene-soluble matter was $10-20 \%$ in the Søderberg departments (15).

Maintenance workers had not been monitored. Maintenance workers in the electrolysis plant were given the average exposure for potmen in the potrooms which operated at the time. Maintenance workers in the carbon plant were assigned the average exposure in the paste plant and furnace area.

Asbestos exposure was assessed on a scale with values 0,1 , and 5 , according to the time spent in exposed work. Daytime work in the foundry and potlining in potrooms A and B were given the value 5, and potlining in the other potrooms was given the value 1 .

Exposure to magnetic fields was estimated from a survey of other Norwegian aluminum smelters (16). This estimate showed a constant relation of $0.06 \mathrm{mT}$ per 1000 amperes of cell current between 2 potlines and suggested average time-varying fields of $1 \mu \mathrm{T}$ for the potrooms and $10 \mu \mathrm{T}$ for the rectifiers. The resulting exposure estimates ranged from 2 to $10 \mathrm{mT}$ for static magnetic fields and from 0.3 to $10 \mu \mathrm{T}$ for time-varying magnetic fields with dominating frequencies of 50,100, and $300 \mathrm{~Hz}$.

Potroom work was classified as heat exposed, and all other work as unexposed.

\section{Individual dose and apparent correlation between the agents}

For each worker, cumulative exposure was calculated for each year under observation as the product of duration and exposure summed for all jobs. Since cumulative exposure was defined as a time-related variable, the correlation between agents potentially related to the same outcome was assessed within the person-time of the cohort. 
Unexposed person-time constituted 1 stratum, and the exposed person-years were divided into 3 strata with roughly equal amounts of person-time. For each pair of agents we cross-tabulated the person-time by the cumulative exposure strata, and the strength of the correlation was assessed with Goodman's and Kruskal's gamma $(\Gamma)$ (12). High correlations were observed for cumulative exposure with time and static magnetic fields $(\Gamma=0.93)$, between cumulative exposure to $\mathrm{PAH}$ and fluoride $(\Gamma=0.89)$. Cumulative heat exposure was correlated to both PAH $(\Gamma=0.89)$ and fluorides $(\Gamma=0.92)$.

\section{Results}

Table 2 shows that the total cancer incidence was not elevated in any of the 3 cohorts. The short-term workers showed a statistically significant excess of lung cancers, and the only cases of pleural mesothelioma were observed in this cohort. In the production cohort the highest standardized incidence ratios (SIR) values were observed for cancers of the lip and rectum, but the only statistically significant finding was a deficit of malignant melanomas. In the maintenance cohort there was a significant excess of lung cancer cases, and the SIR was elevated for cancers of lymphatic and hematopoietic tissue, bladder, and prostate.

\section{Production cohort}

Table 3 shows the analysis of dose-response relations for PAH in the production cohort. Cumulative PAH exposure attained 30 years before observation was associated with an increased incidence of bladder cancer. An association was also observed between $\mathrm{PAH}$ and pancreatic cancer, but this result was not statistically significant. There was no association between cumulative PAH exposure and cancer of the lung or lymphatic and hematopoietic tissue, and the time window analysis did not add any information.

Because of the elevated SIR values for cancers of the lip and colon, we also investigated associations between cumulative PAH exposure and these cancers. A positive association was observed for lip cancer, particularly when exposure was restricted to 30 years before observation. Although not statistically significant, an association was

Table 2. Cancer incidence by total employment among 5908 male aluminum smelter workers in 1953-1993 $(0=$ observed number of cases, $\mathrm{E}=$ expected number of cases, $\mathrm{SIR}=$ standardized incidence ratio, $95 \% \mathrm{Cl}=95 \%$ confidence interval)

\begin{tabular}{|c|c|c|c|c|c|c|c|c|c|c|c|c|}
\hline \multirow[t]{2}{*}{ Cancer site ${ }^{a}$} & \multicolumn{4}{|c|}{$\begin{array}{l}\text { Employed less than } 4 \text { years } \\
\text { ( } \mathrm{N}=2647 ; 65976 \text { person-years) }\end{array}$} & \multicolumn{4}{|c|}{$\begin{array}{c}\text { Production cohort } \\
(\mathrm{N}=2888 ; 71219 \text { person-years })\end{array}$} & \multicolumn{4}{|c|}{$\begin{array}{c}\text { Maintenance cohort } \\
(\mathrm{N}=373 ; 9950 \text { person-years })\end{array}$} \\
\hline & 0 & $\mathrm{E}$ & $S \mid R$ & $95 \% \mathrm{Cl}$ & 0 & $\mathrm{E}$ & SIR & $95 \% \mathrm{Cl}$ & 0 & $E$ & $S \mid R$ & $95 \% \mathrm{Cl}$ \\
\hline All sites & 226 & 210.3 & 107 & $94-122$ & 339 & 325.2 & 104 & $94-116$ & 41 & 34.7 & 118 & $85-160$ \\
\hline Lip (140) & 4 & 2.8 & 143 & $39-367$ & 9 & 4.4 & 204 & $93-387$ & - & 0.5 & - & $0-795$ \\
\hline \multicolumn{3}{|c|}{$\begin{array}{l}\text { Upper respiratory tract } \\
(141,143-8,161)\end{array}$} & 87 & $32-190$ & & 10.5 & 114 & $59-200$ & 2 & 1.2 & 167 & $20-604$ \\
\hline Esophagus (150) & 4 & 2.5 & 161 & $44-412$ & 2 & 4.0 & 50 & $6-180$ & - & 0.4 & - & $0-880$ \\
\hline Stomach (151) & 16 & 16.5 & 97 & $56-158$ & 26 & 27.1 & 96 & $63-141$ & - & 2.7 & - & $0-138$ \\
\hline Colon (153) & 20 & 16.5 & 121 & $74-187$ & 31 & 26.5 & 117 & $80-166$ & 1 & 2.8 & 35 & $1-197$ \\
\hline Rectum (154) & 11 & 10.9 & 101 & $50-180$ & 25 & 17.7 & 141 & $92-209$ & 2 & 1.9 & 106 & $13-381$ \\
\hline Liver (155) & 2 & 1.4 & 138 & $17-499$ & 2 & 2.4 & 84 & $10-305$ & - & 0.2 & - & $0-1490$ \\
\hline Pancreas (157) & 10 & 7.0 & 142 & $68-262$ & 12 & 11.7 & 103 & $53-179$ & 1 & 1.2 & 84 & $2-468$ \\
\hline Lung (162) & 41 & 27.0 & 152 & $109-206$ & 42 & 44.0 & 96 & $69-129$ & 10 & 4.7 & 211 & $101-387$ \\
\hline Pleura (163) & 3 & 0.8 & 386 & $80-1127$ & - & 1.2 & - & $0-302$ & - & 0.1 & - & $0-2645$ \\
\hline Prostate (177) & 31 & 33.2 & 93 & $63-132$ & 62 & 58.9 & 105 & $81-135$ & 9 & 5.7 & 158 & $72-300$ \\
\hline Testis (178) & 4 & 5.4 & 74 & $20-189$ & 5 & 5.0 & 100 & $32-233$ & - & 0.8 & - & $0-471$ \\
\hline Kidney (180) & 9 & 7.9 & 114 & $52-216$ & 13 & 12.3 & 105 & $56-180$ & 1 & 1.4 & 74 & $2-411$ \\
\hline Bladder (181) & 8 & 14.4 & 55 & $24-109$ & 23 & 23.5 & 98 & $62-147$ & 5 & 2.5 & 200 & $65-467$ \\
\hline $\begin{array}{l}\text { Malignant } \\
\text { melanoma (190) }\end{array}$ & 6 & 9.4 & 64 & $23-139$ & 4 & 11.4 & 35 & $10-90$ & 1 & 1.5 & 67 & $2-374$ \\
\hline $\begin{array}{l}\text { Skin (191, excluding } \\
\text { basal cell carcinoma) }\end{array}$ & 6 & 6.1 & 99 & $36-216$ & 7 & 9.9 & 71 & $29-146$ & - & 1.0 & - & $0-356$ \\
\hline $\begin{array}{l}\text { Brain. nervous } \\
\text { system (193) }\end{array}$ & 7 & 7.4 & 94 & $38-194$ & 7 & 9.9 & 71 & $29-146$ & - & 1.2 & - & $0-303$ \\
\hline \multicolumn{10}{|l|}{ Unspecified } & 1.3 & - & $0-278$ \\
\hline \multicolumn{13}{|c|}{ Lymphatic and hematopoietic } \\
\hline tissue $(200-4)$ & 21 & 17.7 & 118 & $73-181$ & 32 & 26.1 & 123 & $84-173$ & 7 & 2.9 & 239 & $96-492$ \\
\hline All other sites & 7 & 8.5 & 82 & $33-169$ & 8 & 6.0 & 134 & $58-264$ & 2 & 0.6 & 346 & $42-1249$ \\
\hline
\end{tabular}

${ }^{a}$ Codes of the International Classification of Diseases (7th revision) in parentheses. 
Table 3. Associations between cumulative polycyclic aromatic hydrocarbon (PAH) exposure and cancer incidence in the production subcohort. $(0=\text { observed number of cases, SIR }=\text { standardized incidence ratio })^{2}$

\begin{tabular}{|c|c|c|c|c|c|c|c|c|c|c|c|c|c|c|}
\hline \multirow[t]{2}{*}{ Cumulative PAH exposure } & \multicolumn{2}{|c|}{ Bladder cancer } & \multicolumn{2}{|c|}{ Pancreas cancer } & \multicolumn{2}{|c|}{ Lung cancer } & \multicolumn{2}{|c|}{$\begin{array}{l}\text { Lymphatic and } \\
\text { hematopoietic } \\
\text { tissue cancer }\end{array}$} & \multicolumn{2}{|c|}{ Lip cancer } & \multicolumn{2}{|c|}{ Colon cancer } & \multicolumn{2}{|c|}{ Rectum cancer } \\
\hline & 0 & $\mathrm{SIR}$ & 0 & SIR & 0 & SIR & 0 & SIR & 0 & SIR & 0 & SIR & 0 & SIR \\
\hline \multicolumn{15}{|l|}{ Unrestricted time window } \\
\hline $\begin{array}{l}0 \\
0-399 \mu \mathrm{g} /\left(\mathrm{m}^{3} \cdot \text { years }\right) \\
400-1199 \mu \mathrm{g} /\left(\mathrm{m}^{3} \cdot \text { years }\right) \\
\geq 1200 \mu \mathrm{g} /\left(\mathrm{m}^{3} \text {.years }\right)\end{array}$ & $\begin{array}{l}4 \\
3 \\
7 \\
9\end{array}$ & $\begin{array}{r}59 \\
73 \\
149 \\
114\end{array}$ & $\begin{array}{l}1 \\
3 \\
2 \\
6\end{array}$ & $\begin{array}{r}28 \\
148 \\
87 \\
157\end{array}$ & $\begin{array}{r}15 \\
6 \\
7 \\
14\end{array}$ & $\begin{array}{r}121 \\
79 \\
77 \\
94\end{array}$ & $\begin{array}{r}14 \\
7 \\
2 \\
9\end{array}$ & $\begin{array}{r}188 \\
141 \\
37 \\
110\end{array}$ & $\begin{array}{r}1 \\
0.8 \\
3 \\
5\end{array}$ & $\begin{array}{r}74 \\
- \\
339 \\
355\end{array}$ & $\begin{array}{r}8 \\
3 \\
3 \\
17\end{array}$ & $\begin{array}{r}103 \\
64 \\
56 \\
195\end{array}$ & $\begin{array}{r}10 \\
2 \\
6 \\
7\end{array}$ & $\begin{array}{r}194 \\
65 \\
169 \\
119\end{array}$ \\
\hline P-value for trend & . & 0.20 & . & 0.13 & . & $>0.3$ & . & 0.09 & . & 0.05 & . & 0.09 & . & $>0.3$ \\
\hline $\begin{array}{l}\text { Time window of } 0-14^{b} \text { yea } \\
\text { 0-399 } \mu \mathrm{g} /\left(\mathrm{m}^{3} \cdot \text { years }\right) \\
400-1199 \mu \mathrm{g} /\left(\mathrm{m}^{3} \cdot \text { years }\right) \\
\geq 1200 \mu \mathrm{g} /\left(\mathrm{m}^{3} \cdot \text { years }\right)\end{array}$ & $\begin{array}{c}\text { befol } \\
15 \\
5 \\
3 \\
1.9\end{array}$ & $\begin{array}{l}\text { observatic } \\
100 \\
126 \\
114 \\
-\end{array}$ & . & $\begin{array}{l}\dot{.} \\
\dot{.}\end{array}$ & $\dot{.}$ & $\dot{.}$ & i. & $\dot{.}$ & $\begin{array}{l}4 \\
2 \\
1 \\
2\end{array}$ & $\begin{array}{l}159 \\
271 \\
164 \\
363\end{array}$ & . & $\dot{s}$ & $\begin{array}{l}. \\
\dot{s}\end{array}$ & . \\
\hline P-value for trend & . & $>0.3$ & . & . & . & . & . & . & . & $>0.3$ & . & . & . & - \\
\hline \multicolumn{15}{|c|}{ Time window of $15-29$ years before observation } \\
\hline $\begin{array}{l}- \\
0-399 \mu \mathrm{g} /\left(\mathrm{m}^{3} \text { years }\right) \\
400-1199 \mu \mathrm{g} /\left(\mathrm{m}^{3} \cdot \text { years }\right) \\
\geq 1200 \mu \mathrm{g} /\left(\mathrm{m}^{3} \text {.years }\right)\end{array}$ & $\begin{array}{l}7 \\
5 \\
7 \\
4\end{array}$ & $\begin{array}{r}68 \\
123 \\
157 \\
84\end{array}$ & $\begin{array}{l}\dot{ } \\
\dot{ }\end{array}$ & $\begin{array}{l}\dot{.} \\
\dot{.}\end{array}$ & . & $\dot{.}$ & $\dot{.}$ & . & $\begin{array}{l}4 \\
1 \\
3 \\
1\end{array}$ & $\begin{array}{l}185 \\
134 \\
394 \\
135\end{array}$ & . & . & $\begin{array}{l}\dot{s} \\
\dot{s}\end{array}$ & $\dot{.}$ \\
\hline P-value for trend & . & $>0.3$ & . & . & . & . & . & . & . & $>0.3$ & . & . & . & . \\
\hline \multicolumn{15}{|c|}{ Time window of $\geq 30$ years before observation } \\
\hline $\begin{array}{l}- \\
0-399 \mu \mathrm{g} /\left(\mathrm{m}^{3} \cdot \text { years }\right) \\
400-1199 \mu \mathrm{g} /\left(\mathrm{m}^{3} \text {.years }\right) \\
\geq 1200 \mu \mathrm{g} /\left(\mathrm{m}^{3} \text {.years }\right)\end{array}$ & $\begin{array}{r}10 \\
3 \\
7 \\
3\end{array}$ & $\begin{array}{r}67 \\
85 \\
221 \\
152\end{array}$ & $\begin{array}{l}\dot{.} \\
\dot{.}\end{array}$ & . & $\dot{.}$ & . & $\dot{.}$ & . & $\begin{array}{r}4 \\
0.5 \\
3 \\
2\end{array}$ & $\begin{array}{r}119 \\
- \\
762 \\
970\end{array}$ & $\dot{.}$ & . & $\dot{.}$ &. \\
\hline P-value for trend & . & 0.03 & . & . & . & . & . & . & . & $<0.01$ & . & . & . & . \\
\hline
\end{tabular}

a Expected number in italics if there were no observed cases.

b The observed and expected cases from the unrestricted analysis were reassigned to the exposure strata according to the amount of cumulative exposure received within the time window.

found between cumulative PAH exposure and cancer of the colon, but not for rectal cancer.

The results of the investigation of the remaining a priori hypotheses is shown in table 4 . There was no association between asbestos and lung cancer, heat and kidney cancer, or between magnetic fields and cancers of the brain or lymphatic and hematopoietic tissue. No excess of the latter cancers was observed among the power plant and rectifier workers of the production cohort, with 2 cases against 1.9 expected.

\section{Maintenance cohort}

The results of the analysis for dose-response relations in the maintenance cohort are shown in table 5. Only $4 \%$ of the person-time was unexposed. Therefore we combined the 2 lower exposure strata. A positive association was observed between cumulative $\mathrm{PAH}$ exposure attained 30 years before observation and lung cancer.

Unlike the case of lung cancer, the excess of lymphatic and hematopoietic cancer was not equally divided between the craftsmen in the maintenance cohort, with 5 cases ( 0.9 expected) among the electricians and 2 cases ( 2.0 expected) among the fitters.

\section{Discussion}

As in a number of previous studies $(2,3-5)$, this current investigation has shown an association between exposure to coal-tar pitch volatiles - here represented by $\mathrm{PAH}$ - and bladder cancer. An association was also observed between PAH exposure and pancreatic cancer. We also observed positive associations between PAH and lip cancer, and between employment as a maintenance electrician and cancers of lymphatic and hematopoietic tissue.

\section{Lung cancer}

One might speculate that the absence of associations between PAH or asbestos and lung cancer in the production cohort may have been due to a negative confounding effect from smoking. This assumption receives some support from the higher SIR for lung cancer among the short-term workers, a finding which suggests a negative correlation between smoking and total employment. This result may extend into the cohorts with longer employment and give rise to a tendency towards decreased smoking with increasing cumulative exposure. 
Table 4. Associations between cumulative exposure to heat, asbestos, or magnetic fields and cancer incidence in the production subcohort. $(0=\text { observed number of cases, SIR = standardized incidence ratio })^{\mathrm{a}}$

\begin{tabular}{|c|c|c|c|c|c|c|c|c|}
\hline \multirow[t]{2}{*}{ Cumulative exposure } & \multicolumn{2}{|c|}{ Lung cancer } & \multicolumn{2}{|c|}{ Kidney cancer } & \multicolumn{2}{|c|}{ Brain cancer } & \multicolumn{2}{|c|}{$\begin{array}{l}\text { Lymphatic and hemato- } \\
\text { poietic tissue cancer }\end{array}$} \\
\hline & 0 & SIR & 0 & $\operatorname{SIR}$ & 0 & SIR & 0 & SIR \\
\hline \multicolumn{9}{|c|}{ Asbestos (intensity-years) } \\
\hline - & 31 & 99 & . & . & . & . & & . \\
\hline $0.0-1.4$ & 4 & 105 & . & . & . & . & . & \\
\hline $1.4-6.9$ & 4 & 122 & . & . & . & . & . & . \\
\hline$\geq 7.0$ & 3 & 54 & . & . & . & . & . & . \\
\hline P-value for trend & . & $>0.3$ & . & . & . & . & . & . \\
\hline \multicolumn{9}{|l|}{ Heat (years) } \\
\hline & . & . & 4 & 88 & . & . & . & . \\
\hline $0.0-4.9$ & . & . & 2 & 87 & . & & . & \\
\hline $5.0-10.9$ & . & . & 1 & 51 & . & . & . & . \\
\hline$\geq 11.0$ & . & . & 6 & 170 & . & . & . & . \\
\hline P-value for trend & . & . & . & $>0.3$ & . & . & & \\
\hline \multicolumn{9}{|c|}{ Static magnetic fields (mT years) } \\
\hline- & . & . & . & . & 3 & 87 & 15 & 151 \\
\hline $0.0-13.9$ & . & . & . & . & 2.0 & & 7 & 134 \\
\hline $14.0-44.9$ & . & . & . & . & 2 & 103 & 5 & 104 \\
\hline$\geq 45.0$ & . & . & . & . & 2 & 82 & 5 & 82 \\
\hline P-value for trend & . & . & . & . & . & $>0.3$ & . & 0.20 \\
\hline \multicolumn{9}{|c|}{ Time-varying magnetic fields ( $\mu$ T years) } \\
\hline- & . & . & . & . & 3 & 90 & 15 & 157 \\
\hline $0.0-4.9$ & . & & . & . & 1 & 44 & 8 & 143 \\
\hline $5.0-9.9$ & . & . & . & . & 1.7 & - & 1 & 25 \\
\hline$\geq 10.0$ & . & . & . & . & 3 & 116 & 8 & 115 \\
\hline P-value for trend & . & . & . & . & . & $>0.3$ & . & 0.24 \\
\hline
\end{tabular}

${ }^{a}$ Expected number in italics if there were no observed cases.

Table 5. Associations between cumulative polycyclic aromatic hydrocarbon (PAH) exposure and cancer incidence in the maintenance cohort. $(0=\text { observed number of cases, SIR }=\text { standardized incidence ratio })^{\mathrm{a}}$

\begin{tabular}{|c|c|c|c|c|c|c|}
\hline \multirow[t]{2}{*}{ Cumulative PAH exposure } & \multicolumn{2}{|c|}{ Lung cancer } & \multicolumn{2}{|c|}{ Bladder cancer } & \multicolumn{2}{|c|}{$\begin{array}{l}\text { Lymphatic and hematopoietic } \\
\text { tissue cancer }\end{array}$} \\
\hline & 0 & $\operatorname{SIR}$ & 0 & $\operatorname{SIR}$ & 0 & SIR \\
\hline \multicolumn{7}{|l|}{ Unrestricted time window } \\
\hline $\begin{array}{l}<400 \mu \mathrm{g} /\left(\mathrm{m}^{3} \cdot \text { years }\right) \\
400-1199 \mu \mathrm{g} /\left(\mathrm{m}^{3} \cdot \text { years }\right) \\
\geq 1200 \mu \mathrm{g} /\left(\mathrm{m}^{3} \cdot \text { years }\right)\end{array}$ & $\begin{array}{r}0.3 \\
2 \\
8\end{array}$ & $\begin{array}{r}- \\
139 \\
266\end{array}$ & $\begin{array}{l}1 \\
1 \\
3\end{array}$ & $\begin{array}{l}716 \\
125 \\
192\end{array}$ & $\begin{array}{r}1 \\
0.9 \\
6\end{array}$ & $\begin{array}{r}328 \\
- \\
353\end{array}$ \\
\hline P-value for trend & . & 0.23 & & $>0.3$ & . & $>0.3$ \\
\hline \multicolumn{7}{|c|}{ Time window of $0-14^{b}$ years before observation } \\
\hline $\begin{array}{l}<400 \mu \mathrm{g} /\left(\mathrm{m}^{3} \cdot \text { years }\right) \\
400-1199 \mu \mathrm{g} /\left(\mathrm{m}^{3} \text {.years }\right) \\
\geq 1200 \mu \mathrm{g} /\left(\mathrm{m}^{3} \text {.years }\right)\end{array}$ & $\begin{array}{l}7 \\
2 \\
1\end{array}$ & $\begin{array}{r}297 \\
159 \\
89\end{array}$ & : & : & i. & $\dot{.}$ \\
\hline P-value for trend & & 0.19 & . & . & . & . \\
\hline \multicolumn{7}{|c|}{ Time window of $15-29$ years before observation } \\
\hline $\begin{array}{l}<400 \mu \mathrm{g} /\left(\mathrm{m}^{3} \cdot \text { years }\right) \\
400-1199 \mu \mathrm{g} /\left(\mathrm{m}^{3} \cdot \text { years }\right) \\
\geq 1200 \mu \mathrm{g} /\left(\mathrm{m}^{3} \cdot \text { years }\right)\end{array}$ & $\begin{array}{l}3 \\
3 \\
4\end{array}$ & $\begin{array}{l}190 \\
241 \\
208\end{array}$ & i & : & i. & : \\
\hline P-value for trend & & $>0.3$ & . & . & . & . \\
\hline \multicolumn{7}{|c|}{ Time window of $\geq 30$ years before observation } \\
\hline $\begin{array}{l}<400 \mu \mathrm{g} /\left(\mathrm{m}^{3} \cdot \text { years }\right) \\
400-1199 \mu \mathrm{g} /\left(\mathrm{m}^{3} \cdot \text { years }\right) \\
\geq 1200 \mu \mathrm{g} /\left(\mathrm{m}^{3} \cdot \text { years }\right)\end{array}$ & $\begin{array}{l}3 \\
5 \\
2\end{array}$ & $\begin{array}{l}104 \\
422 \\
292\end{array}$ & i. & : & : & ; \\
\hline P-value for trend & & 0.12 & . & & . & . \\
\hline
\end{tabular}

a Expected number in italics if there were no observed cases.

${ }^{b}$ The observed and expected cases from the unrestricted analysis have been reassigned to the exposure strata according to the amount of cumulative exposure received within the time window. 
True associations between PAH and asbestos and lung cancer may also have remained undetected if the 2 exposures were negatively correlated. However, crosstabulation of the person-time by cumulative exposure to the 2 agents showed a positive correlation, and one would expect this to result in a positive rather than a negative confounder (17).

A more plausible explanation for the negative results for $\mathrm{PAH}$ and lung cancer could be the lower exposure levels or shorter follow-up than in the 2 studies which have shown a positive association between tar exposure and lung cancer among aluminum workers $(3,6)$. Both concerned a smelter at Arvida, Quebec, for which the estimated benzo[a]pyrene concentrations (6) suggested that PAH levels may have been $50 \%$ higher than those at Årdal before 1960 (table 1).

Although not statistically significant, the result for PAH and lung cancer in the maintenance cohort provides some support for the earlier Canadian findings $(3,6)$. Exposure to asbestos may also have been of some importance in this group, but the maintenance workers are not believed to have experienced any higher exposures than the members of the production cohort who had been classified as asbestos-exposed. In the latter cohort the use of semiquantitative exposure scores may have introduced some dose misclassification, but this possibility cannot explain why the incidence of lung cancer in the exposed strata (SIR $=87$ ) was no higher than that in the unexposed stratum (SIR = 98). To our knowledge the Årdal smelter had only used chrysotile, which may carry a lower risk than the amphiboles (18). It is also possible that the exposure levels had been too low to cause a detectable increase in cancer incidence.

\section{Bladder cancer}

Although studies in the aluminum industry (3-5) have focused on the association between exposure to coal-tar pitch volatiles and bladder cancer risk, fluorides have also been implicated as a cause of bladder cancer (19). All the potrooms at Ardal used Søderberg anodes until 1959, and in this type of potroom exposure to $\mathrm{PAH}$ and fluorides has been strongly correlated. However, this correlation received no support from the Eydehavn study, in which the 2 exposures were negatively correlated (2). As in the Eydehavn study (2), the present results suggest a latency period of 30 years before the diagnosis of bladder cancer in relation to PAH exposure.

\section{Cancers of the brain and lymphatic and hematopoietic tissue}

Previous studies of electromagnetic fields and lymphatic and hematopoietic cancers have produced conflicting results. Employment in "electrical occupations" has repeatedly been associated with increased risk (20), whereas studies based on quantitative exposure estimates have produced negative or equivocal results $(21-24)$. In the present study the absence of an association with magnetic field exposure in the production cohort was contrasted by a statistically significant, positive association with employment as a maintenance electrician.

The maintenance electricians had mainly worked with 220-V alternating current, and they were known to have had frequent exposure to electric discharges, which have been proposed as a cause of chromosome aberrations (25, 26). Awareness against electric shock has been much higher in the power plants, rectifiers, and potlines of the smelter, due to the higher voltages or much stronger currents. The present results suggest that exposure to electric discharges should be considered in future studies of cancer among electrical workers.

\section{Other cancers}

Although not statistically significant, the association observed between $\mathrm{PAH}$ exposure and pancreatic cancer provides some support for the increased mortality from this disease reported among potroom workers in the United States (27). The excess of kidney cancers in the highest dose stratum for heat exposure lends some support to the association previously observed at the Eydehavn smelter (2).

The associations observed between PAH and cancers of the lip and colon may well be due to coincidence. However, tar exposure has been proposed as a cause of gastrointestinal cancer among coke plant workers (28).

\section{Methodological implications}

The present results suggest that the sensitivity of a doseresponse analysis can be sharpened by the use of a dose indicator which accounts for the time course of induction and latency. Together with the Eydehavn study (2), the present results suggest a latency period of 30 years or more for bladder cancer induced by coal-tar pitch volatiles.

A comparison of the SIR values of the production subcohort suggests that the inclusion of short-term workers in the dose-response analysis might have confounded the results for cancers of the lungs and pancreas. One may also argue that important information about associations with cancers of the lungs and lymphatic and hematopoietic tissue would have remained undetected if the maintenance workers had not been analyzed separately.

\section{Acknowledgments}

This work was part of a project supported by grants from the Work Environment Fund of the Confederation of Norwegian Business and Industry and The Nordic Aluminum Industry's Secretariat for Health, Environment and Safety. We acknowledge the support from the project 
committee members Erle Grieg Astrup, Anders Bruusgaard, Øyvind O Johansen, Frøydis Langmark, Sverre Langård, and Eirik Nordheim. Elisabeth Moe established the personnel register and Oddvar Sandvin designed all the programs used with the Epicure software.

\section{References}

1. Andersen A, Dahlberg BE, Magnus K, Wannag A. Risk of cancer in the Norwegian aluminium industry. Int J Cancer 1982;29:295-8.

2. Rønneberg A, Andersen A. Mortality and cancer morbidity in workers from an aluminium smelter with prebaked carbon anodes-part II: cancer morbidity. Occup Environ Med 1995;52:250-4.

3. Gibbs GW. Mortality of aluminum reduction plant workers, 1950 through 1977. J Occup Med 1985;27:761—70.

4. Spinelli JJ, Band PR, Svirchev L, Gallagher RP. Mortality and cancer incidence in aluminum reduction plant workers. $J$ Occup Med 1991;33:1150-5.

5. Tremblay C, Armstrong B, Thériault G, Brodeurs J. Estimation of risk of developing bladder cancer among workers exposed to coal tar pitch volatiles in the primary aluminum industry. Am J Ind Med 1995;27:335-48.

6. Armstrong B, Tremblay C, Baris D, Thériault G. Lung cancer mortality and polynuclear aromatic hydrocarbons: a case-cohort study of aluminum production workers in Arvida, Quebec, Canada. Am J Epidemiol 1994;139:250-62.

7. Andersen A. Cancer mortality and morbidity in Norway. In: Hughes JP, editor. Health protection in primary aluminium production; vol 2. London: International Primary Aluminium Institute, 1982:49-52.

8. Rønneberg A, Langmark F. Epidemiologic evidence of cancer in aluminium reduction plant workers. Am J Ind Med 1992;22:573-90.

9. Rothman KJ. Induction and latent periods. Am J Epidemiol 1981;114:253-9

10. Preston DL, Lubin JH, Pierce DA, McConney ME. Epicure. Seattle (WA): Hirosoft International Corporation, 1993.

11. Breslow NE, Day NE. Statistical methods in cancer research; vol II (The design and analysis of cohort studies). Lyon: International Agency for Research on Cancer, 1987:96-7.

12. Dixon WJ. BMDP statistical software manual volume 1: to accompany BMDP release 7. Berkely (CA): University of California Press, 1992.

13. Bjørseth A, Bjørseth O, Fjeldstad PE. Polycyclic aromatic hydrocarbons in the work atmosphere, I: determination in an aluminum reduction plant. Scand J Work Environ Health 1978:4:212-23.

14. Farant JP, Manon G. Relationship between benzo(a)pyrene and individual polycyclic aromatic hydrocarbons in a Søderberg primary aluminum smelter. Am Ind Hyg Assoc J 1998;59:758-65.

15. Romundstad P, Haldorsen T, Rønneberg A. Exposure to PAH and fluoride in aluminum reduction plants in Norway: historical estimation of exposure using process parameters and industrial hygiene measurements. Am J Ind Med 1999;35:2:164-74.

16. Thommesen G, Bjølseth P. Statiske og lavfrekvente magnetfelt i norske smelte- og elektrolyseverk [Static and low frequency magnetic fields in Norwegian alloy and electrolysis plants]. Oslo: National Institute of Radiation Hygiene, 1992.

17. Steenland K, Beaumont J, Halperin W. Methods of control for smoking in occupational cohort mortality studies [review] Scand J Work Environ Health 1984;10:143-9.

18. Doll $\mathrm{R}$. Mineral fibres in the non-occupational environment: concluding remarks. In: Bignon J, Peto J, Saracci R, editors. Non-occupational exposure to mineral fibres. Lyon: International Agency for Research on Cancer, 1989:511-8.

19. Grandjean P, Olsen JH, Jensen OM, Juel K. Cancer incidence and mortality in workers exposed to fluoride. JNCI 1992;84:1903-9.

20. Savitz DA. Overview of epidemiologic research on electric and magnetic fields and cancer. Am Ind Hyg Assoc J 1993;54:197-204.

21. Tynes T, Reitan JB, Andersen A. Incidence of cancer among workers in Norwegian hydroelectric power companies. Scand J Work Environ Health 1994;20:339-44.

22. Savitz DA, Loomis DP. Magnetic field exposure in relation to leukemia and brain cancer mortality among electric utility workers. Am J Epidemiol 1995;123-34.

23. Baris D, Armstrong B, Deadman J, Thériault G. A mortality study of electrical utility workers in Québec. Occup Environ Med 1996;53:25-31.

24. Miller AB, To T, Agnew DA, Wall C, Green LM. Leukemia following occupational exposure to $60-\mathrm{Hz}$ electric and magnetic fields among Ontario electric utility workers. Am J Epidemiol 1996;144:150-60.

25. Nordenson I, Hansson Mild K, Östman U, Ljungberg H. Chromosomal effects in lymphocytes of $400 \mathrm{kV}$-substation workers. Radiat Environ Biophys 1988;27:39-47.

26. Skyberg K, Hansteen I-L, Vistnes AI. Chromosome aberrations in lymphocytes of high-voltage laboratory cable splicers exposed to electromagnetic fields. Scand $\mathbf{J}$ Work Environ Health 1993;19:29-34.

27. Rockette HE, Arena VC. Mortality studies of aluminum reduction plant workers: potroom and carbon department. J Occup Med 1983;25:549-57.

28. Berger J, Manz A. Cancer of the stomach and the colonrectum among workers in a coke gas plant. Am J Ind Med $1992 ; 22: 825-34$

Received for publication: 8 December 1998 